\title{
Bangladesh 2000-2017: Sustainable Growth, Technology and the Irrelevance of Productivity
}

\section{Matthew McCartney*}

\begin{abstract}
This paper focuses on the case of Bangladesh as an example of a country that is at risk of falling into the 'middle income trap', in other words the risk that a country that has attained middle income levels will then be unable to join the $c l u b$ of developed countries. This paper uses the theory of Unequal Exchange from the Dependency School to understand the middle income trap in Bangladesh and further argues that the ideas of productivity, competitiveness and technological change derived from orthodox economic thinking are not useful in understanding growth prospects and policy responses in contemporary middle income countries. Alternately, the paper explains the role of structural change as a means of sustaining growth in middle income countries.
\end{abstract}

Keywords: Bangladesh, middle income trap, unequal exchange, structural change.

JEL Classification: O40, O14.

\section{Introduction}

In recent years, Bangladesh has unobtrusively joined two prestigious clubs; those of the "economic successes" and also the "development successes". Steady economic growth over recent decades has continued throughout global and regional crises and seen Bangladesh attain middle income level status. A striking ability to translate this economic growth into improvements in human welfare - higher literacy and life expectancy and lower child mortality and female fertility, for example - has seen Bangladesh being tentatively added to an even more exclusive list. This is the short list containing the Indian state of Kerala, China in the 1970s, Costa Rica, Cuba and very few others - those states or countries that have made striking achievements in human welfare despite low levels of national income. In 2017, Bangladesh begins to face new challenges that have emerged as a result of this success. Bangladesh faces

\footnotetext{
${ }^{*}$ Professor, School of Interdisciplinary Area Studies, Oxford University.
} 
a transition towards facing market prices for imported pharmaceutical products and is no longer able to rely on an aura of hopeless poverty to access them at steeply discounted rates. This paper focuses on a new economic threat, one that is again paradoxically a product of success. This is the "middle income trap" or the fear that countries who have successfully attained middle income level (roughly GDP per capita of USD 1000-5,000) will then be unable to sustain their prior growth momentum and go on to become developed countries. While utilizing this new organizing concept this paper uses an old-fashioned theoretical perspective - that of Unequal Exchange from the Dependency School to make sense of the middle income trap in Bangladesh. This paper argues that the ideas of productivity, competitiveness and technological change derived from orthodox economic thinking are not useful starting points in thinking about growth prospects and policy responses in contemporary Bangladesh. Instead, Unequal Exchange points towards the importance of structural change as a means to sustain growth in contemporary Bangladesh. While the analysis is clear this paper does not have an optimistic conclusion as it suggests that countries like Bangladesh lack the state capacity to pursue this policy goal.

This paper is organized as follows. Section 2 introduces the idea of Bangladesh as a growth and development success story, section 3 introduces and illustrates the idea of the middle income trap, section 4 discusses the orthodox view of competitiveness, productivity and technology, section 5 makes a case for an old-fashioned economic theory that of Unequal Exchange - to think about contemporary Bangladesh and section 6 concludes.

\section{Bangladesh: A Growth and Development Success Story}

In the early 1970s, Henry Kissinger, the US Secretary of State, called Bangladesh a "basket case". This referred to the widespread view that the country was socially and economically non-viable. Bangladesh was an agricultural economy suffering from famine; it was dependent on the exports of raw jutes to be processed by mills in Pakistan, a market now severed by civil war and independence, and it was dependent on foreign aid to preserve its normal social and economic functioning. Thirty years later, Bangladesh by contrast was widely perceived to be an economic success story. During the 2000s the Bangladeshi economy has been growing at more than 6 percent per annum. The years 2011 to 2015, which saw a slowdown in various emerging economies, including India, saw by contrast broad-based growth in Bangladesh: in agriculture (2.5-4.4 
percent), in industry (8-10 percent) and in services (5-7 percent). Over the 2000s, other indicators pointed to the likely sustainability of this growth; inflation fell (11 to 6.5 percent), investment as a share of GDP remained steady (27-28 percent), and debt service as a share of GDP declined (17 to 12 percent) (Asian Development Bank, 2016). Bangladesh is now even being talked up as a human-development success story. Although India has outpaced Bangladesh in terms of growth over the last two decades, "in terms of many typical indicators of living standards, Bangladesh not only does better than India, it has a considerable lead over it" (Dreze \& Sen, 2013, p. ix). Evidence for this proposition is not hard to find: Between 1990 and 2015, life expectancy at birth increased from 56 to 71, adult literacy increased from 37 to 64.6 percent, primary school enrollment increased from 56 to 109 percent, and child malnutrition declined from 61.5 to 32.6 percent (Asian Development Bank, 2016). Figure 1 reveals this story: the economic decline after the late-1960s and the steady economic growth after 1990, not interrupted by the 1997 Asian Crisis, 2001 DotCom crisis or by the 2008 Global Financial Crisis.

\section{Figure 1: GDP per capita in Bangladesh 1967 to 2015 (2010 constant \$)}

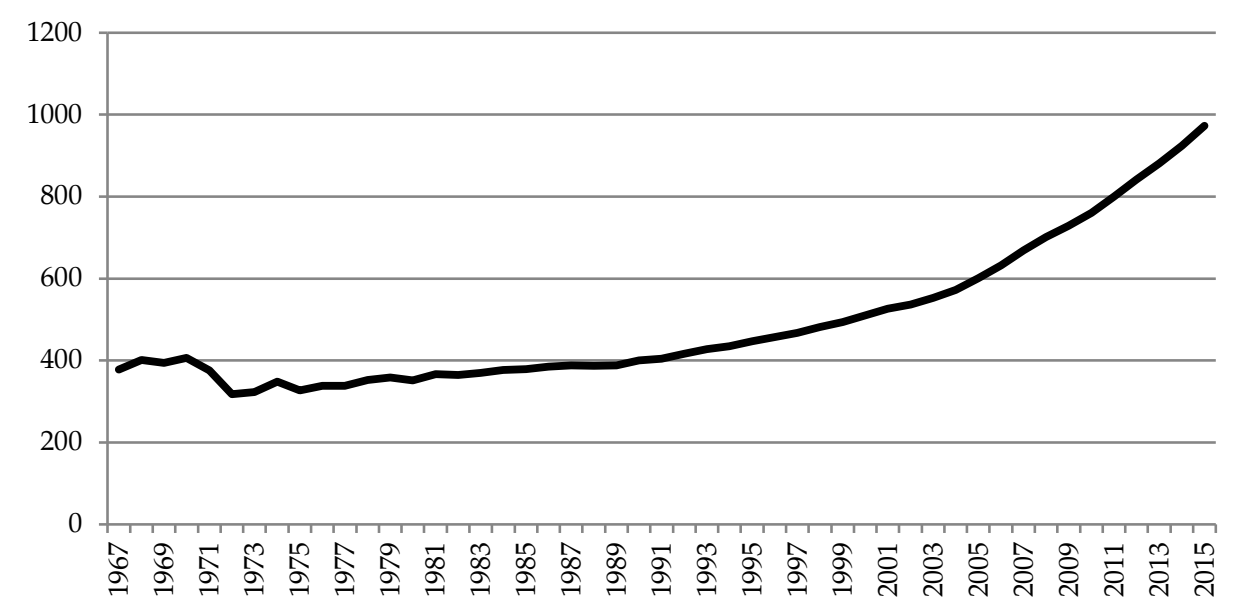

Source: World Bank (2017b)

\section{Bangladesh and the Middle Income Trap}

While lauding long years of steady economic growth in Bangladesh and similar successful developing countries, various scholars have voiced concerns about the likely medium to long term sustainability of this growth. This is part of a wider discussion that acknowledges the success of 
various developing countries that have achieved rapid GDP growth and reached the status of middle income countries (Bangladesh was thought to have achieved this status by 2015) but also that sustaining growth beyond this point represents a new and more difficult challenge. There was a consequent risk of Bangladesh and others falling into a middle-income trap of economic stagnation (Felipe et al., 2012). Figure 2 shows the reality of such a trap. Between 1960 and 1980, both Brazil and South Korea experienced rapid economic growth and both achieved middle-income status. After 1980, South Korea sustained that growth such that the Asian Crisis of 1997 and Global Financial Crisis of 2008 have had only a relatively minor impact and are dominated by a longer term upward trajectory. Economic growth in Brazil, by contrast stalled after 1980, and by 2014, GDP per capita was only slightly higher than it had been thirty years earlier.

Figure 2: GDP Per Capita in Brazil and South Korea, 1960 to 2014 (constant 2005 US\$)

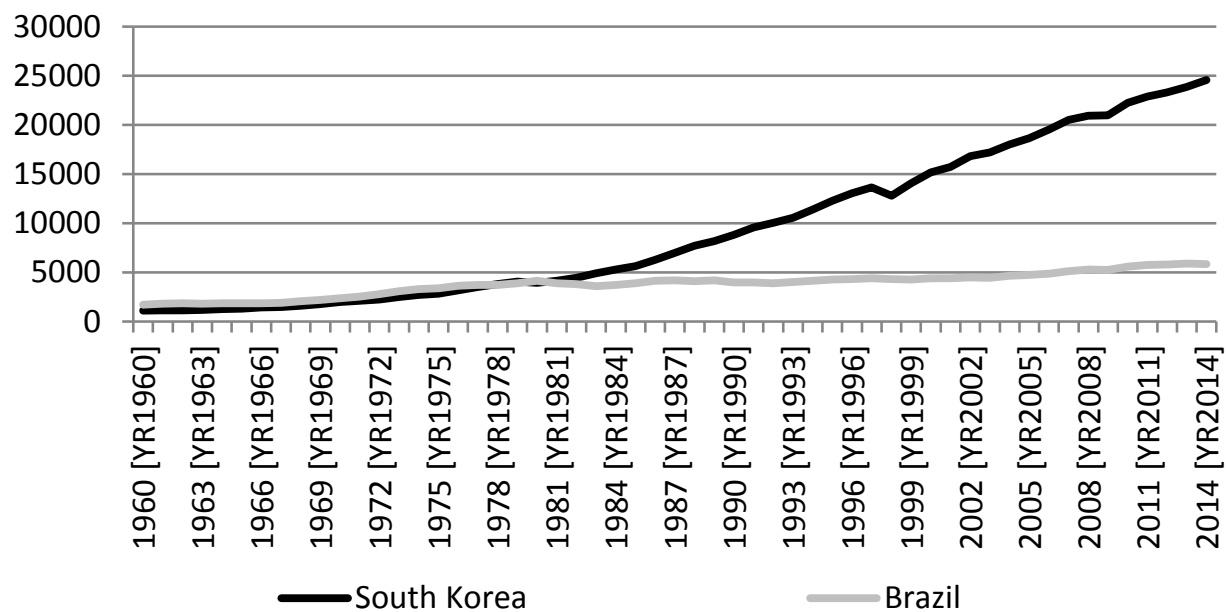

Source: World Bank (2017b)

\section{The Orthodox View: Productivity, Competitiveness and Technology}

The orthodox theoretical perspective used to understand countries like Bangladesh can be seen in Figure 3. This illustrates how Bangladesh has grown since the 1970s based on accumulating more factors of production, notably capital and labor. Investment has increased from negligible levels to around 27 percent of GDP and literacy rates and primary school enrolment doubled in the twenty five years after 1990. This growth was was export-led and these exports mostly comprised of ready- 
made garments which expanded from negligible levels in the late 1970s (US\$ 40,000 in 1977) to 3,500 factories in the mid-1990s and by 2010 readymade garments exports topped US\$ 16 billion. Export growth was structured around bringing women into the labor force, with the percentage of women in manufacturing rising from around 4 percent in 1974 to 55 percent in 1995/96 when the sector employed around 1.5 million women (Kabeer \& Mahmud, 2004). This pattern of growth can be represented by a move from the origin of Figure 3 (in 1970) to point A (in 2017) which is associated with GDP per capita rising to GDP ${ }_{1}$. After this point, there are diminishing returns to accumulating more labor and capital. In Bangladesh, the empirical evidence supports this theoretical perspective; there are growing shortages of young women able to enter the labor force. There is good evidence that real wage growth in Bangladesh has accelerated since the early 2000s as "the supply of seemingly unlimited labor was exhausted, the terms of trade in the labor market started to shift in favour of workers, leading to a tightening labor market and an increase in agricultural wages." (Zhang et al., 2014, p. 274). This has been accompanied by lower returns to human capital and empirical studies show declining social returns to education after the primary level across a broad cross-section of countries (Psacharopoulos, 1994). This is the reality of the middle income trap as it begins: Continuing with the same growth strategy that has successfully sustained growth to point A (roughly middle-income level) will run into diminishing returns to accumulation and slowing economic growth. The orthodox way of thinking about how best to sustain economic growth in Bangladesh and other middle income developing countries is that escaping the middle income trap requires a shift in development strategy. This shift would need to utilize new technology to boost the productivity of existing factors of production, which in turn would shift the production possibility curve in Figure 3, leading to sustained economic growth and raising GDP per capita to GDP 2 . 
Figure 3: Sustainable Growth in Bangladesh

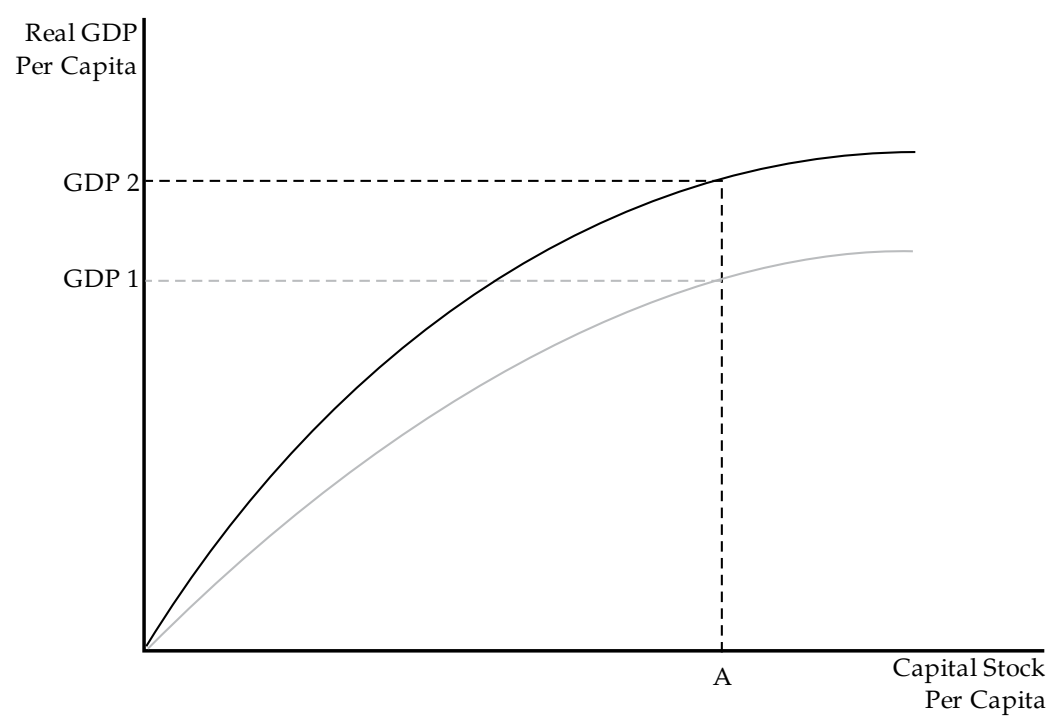

One way in which this thinking has proved influential is in terms of the idea of "competitiveness". The World Economic Forum has been publishing the Global Competitiveness Report and its associated competitiveness index since 2004. The 2015/16 report noted that we "define competitiveness as the set of institutions, policies and factors that determine the level of productivity of an economy, which in turn sets the level of prosperity that the country can earn." (World Economic Forum, 2015, p. 4). The World Bank shares this same understanding: Productivity, "is what drives competitiveness in the long run, and boosting productivity leads to rising living standards through higher wages and returns in investment." (World Bank, 2017a, p. 18).

The measure of competitiveness produced by the 2015/16 Global Competitiveness Report combines 114 indicators that are further combined into 12 "pillars"1. These pillars are institutions, infrastructure,

\footnotetext{
${ }^{1}$ In the 2015/16 Global Competitiveness Bangladesh rated $107^{\text {th }}$ from 140 countries (World Economic Forum, 2015, p. xv). This ranking represented a gradual improvement, from $118^{\text {th }}$ in $2012 / 13,110^{\text {th }}$ in $2013 / 14$, and $109^{\text {th }}$ in $2014 / 15$. Over this same time period, Bangladesh's overall competitiveness score (out of 7.0) increased from 3.6 to 3.8. In 2015/16 Bangladesh rated well on its macroeconomic environment (5.0 out of 7.0), market size (4.7) and health and primary education (5.2), but poorly on higher education and training (2.9), infrastructure (2.6), institutions (2.9) and innovation (2.7). Among the more disaggregated components of the various pillars Bangladesh does well in regard to the strength of investor protection where it ranks $42^{\text {nd }}$ out of 140 countries, General government debt, $46^{\text {th }}$, HIV prevalence joint $1^{\text {st }}$, the total tax rate $49^{\text {th }}$, legal rights $44^{\text {th }}$ and domestic market size $32^{\text {nd }}$. Bangladesh does less well on irregular payments and bribes $139^{\text {th }}$, efficiency of the
} 
macroeconomic environment, health and primary education, higher education and training, goods market efficiency, labor market efficiency, financial market development, technological readiness, market size, business sophistication and innovation (World Economic Forum, 2015, p. 5). The ninth pillar is "technological readiness" which "measures the agility with which an economy adopts existing technologies to enhance the productivity of its industries........firms operating in the country need to have access to advanced products and blueprints and the ability to absorb and use them" (World Economic Forum, 2015, p. 36). The report understands technology as "a broad concept covering not only products such as machinery, equipment, and material, but also processes and organization methods, all linked by the common factor of enhancing efficiency in production" (World Economic Forum, 2015, p. 52). The logic behind this is clearly that technology boosts productivity and higher productivity sustains economic growth.

Policy recommendations stemming from the competitiveness paradigm on how to boost productivity focus on facilitating the use of new technology by making markets work better. The reasoning is that better functioning markets will increase the competitive pressure on Bangladeshi firms to utilize new technologies and facilitate the efficient access of such firms to global technologies at low cost. For example World Bank (2017a, p. 37) describes the investment climate as "the environment which determines entrepreneurs' ability to work efficiently, such as the degree of difficulty in accessing production inputs and dealing with regulatory and legal requirements, and the level of security in running operations and obtaining payments". The report notes with approval that various new government initiatives have improved the functioning of markets - that the Economic Zones Act of 2010 has improved incentives, the Competition Law has leveled the playing field for businesses, the Value Added Tax (VAT) has reduced the cost of compliance, regulatory reforms have eased business registration, trademark and patent registration, and simplified licenses and construction permits (World Bank 2017a, p. 42). The World Bank (2016, p. 103) continues along the same lines and argues that "Bangladesh needs to address the fundamental drivers of global [value] chains, such as lowering the trade costs and barriers to services". And the same report argues that foreign investors are "confronted with major regulatory issues ranging from entry and establishment, taxation, access to skills and land, foreign exchange regulations, corruption and public governance." (World Bank, 2016, p. 251).

legal framework in settling disputes $131^{\text {st }}$, reliability of police services $136^{\text {th }}$, ethical behaviour of firms $135^{\text {th }}$, country capacity to attract talent $122^{\text {nd }}$, and university-industry collaboration in R\&D $131^{\text {st }}$ (World Economic Forum, 2015, p. 108-9). 


\section{Unequal Exchange and Old-fashioned Economics}

The very general diagnostics of thinking rooted in competitiveness ignores the very specific and peculiar conditions of economic growth in contemporary Bangladesh. At first glance, productivity would appear to be crucial in any long term strategy to sustain economic growth in Bangladesh. Exports from Bangladesh grew by 13 percent per annum between 2000 and 2013, at the end of which Bangladesh had only a 0.2 percent share of the global market, implying that there is clearly scope to increase exports further from Bangladesh. Also exports from Bangladesh have been concentrated in low cost, low value added textiles. This focus has resulted in a growing movement among the international community of textile buyers to pressure Bangladesh into raising labor standards, including wages ${ }^{2}$. This would require Bangladesh to shift to a productivity led growth strategy to raise wages (and improve labor conditions) whilst remaining competitive in world markets. But let us pause at this point to question this easy assumption. Without thinking carefully about the precise nature of such a productivity-led strategy, the effort could run into significant problems. This is where one particular strand of dependency thinking - that of Unequal Exchange; can better help us understand the situation in contemporary Bangladesh.

The Dependency School of economics is the old-fashioned economics that will help us to better understand the constraints and opportunities facing the economy of Bangladesh in recent times. The Dependency School flourished in the 1960s and 1970s and took as its starting point the idea that the prospects for economic growth in a developing country are principally determined not by competitiveness or the functioning of markets but by its structural position in the international economy (Hunt, 1989). Industrial development in a developing country is dependent on markets, technology, brand names, services such as insurance and marketing and also foreign capital originating in developed countries. The analytical frameworks of the Dependency School revolve around how profit (known as an economic surplus) is extracted by the developed world from the developing world. The means by which this surplus is extracted have varied and include colonial era

\footnotetext{
${ }^{2}$ A key point of that vulnerability remains over concerns about labor standards in Bangladesh and the possible reaction of importing countries. In June 2013, for example, the US suspended trade privileges granted to Bangladesh - the Generalized System of Preferences (GSP). The move was in response to concerns over safety and labor rights violations in the garments sector and in particular a reaction to the disaster at the Rana Plaza building in Dhaka. At the same time, 190 mostly European global apparel brands agreed a legally binding plan to inspect Bangladeshi garment factories and provide publicly available inspection reports. By September 2014, 1,103 factories had been inspected resulting in reports of 52,605 safety issues (World Bank, 2016, p. 17).
} 
plunder and enforced trade, excessive profits earned by monopolistic MNC investment, technological dependence and associated royalty payments, and debt and consequent financial transfers (Dos Santos, 1970; Palma, 1978). This extraction, goes the argument, reduces the prospects for economic growth in the developing world. The more extreme versions of the Dependency School argue that such a dependent relationship will completely inhibit growth in the developing world. That "contemporary underdevelopment is in large part the historical product of past and continuing economic and other relations between the satellite underdeveloped and the now-developed metropolitan countries," and that "the structure and development of the capitalist system as a whole account for its simultaneous generation of underdevelopment in some of its parts and of economic development in others." (Frank, 1966, 5). The more moderate versions argue that in order to understand the economic growth of developing countries (such as Bangladesh) it is necessary to understand the general functioning of the world capitalist system and that economic growth and development in developing countries is possible but will be "a kind of dependent capitalist development in the sectors of the Third World integrated into the new forms of monopolistic expansion." (Cardoso, 1972, p. 89).

Export and hence economic growth in Bangladesh are clearly dependent on developed country markets. Although export growth was relatively rapid in Bangladesh (by 11.2 percent per annum between 2000/01 and 2009/10), there was a concern about what some have labelled the "Walmart Effect". The vast majority of Bangladeshi exports (96 percent) to the US are concentrated in ready-made garments and textile products and principally bought by cheaper retailers such as Walmart and Target. Measures of the "sophistication" of exports from Bangladesh have shown little change over the 2000s. By contrast, measures of sophistication have increased significantly in Vietnam, where cell phones and accessories overtook garments in the country's export profile over the 2000s. In addition to product categories, the destination of Bangladesh's exports has been very concentrated. Two-thirds of all exports went to the EU and the US (World Bank, 2016, p. 10), illustrating that export growth from Bangladesh over the last decade has been based around increasing exports to existing markets. Those exports were also driven by incumbents increasing output. Between 1998 and 2008 the top five textile exporters from Bangladesh remained the same, while in China only one remained in the top five. This is also shown by the low rate of entry and exit of firms in the garment sector in Bangladesh (World Bank, 2016, p. 26). 
This increasing degree of specialization and dependence is very unusual. While the share of garments in total exports from Bangladesh increased from 77 to 84 percent between 2000 and 2012, it declined in China, Vietnam, India, and Pakistan (though did grow in Sri Lanka). The empirical evidence shows that developing countries tend to diversify their production and export structures as they experience sustained economic growth (Imbs \& Wacziarg, 2003). Only at relatively higher levels of income (around the GDP per capita of Ireland) is further growth associated with increased specialization. This effect is not capturing a structural transformation from agriculture to industry but rather is driven by a process of diversification and expansion of the range of activities within manufacturing (Rodrik, 2006).

The most relevant work within the Dependency School is that of Arghiri Emmanuel and his theory of Unequal Exchange. Emmanuel (1972) argued that the root cause of underdevelopment lies in the exchange relations between developed and developing countries. He argued that under certain conditions, countries can become net losers through international trade which is a striking difference from the orthodox theory of comparative advantage. Emmanuel argued that capital is mobile while labor is not and that the rate of profit is equalized in all countries (assumptions which are reasonable approximations for contemporary Bangladesh). Under these conditions the ratio at which products are exchanged is determined not by the forces of demand and supply in international markets but by the domestic costs of production in developing and developed countries. Free movement of foreign direct investment (FDI) in the global economy means that capital costs can be assumed to be uniform internationally, but controls on the migration of people mean that wage costs differ dramatically between developed and developing countries leading to price differentials in production, especially in labor-intensive sectors like cheap textiles. The higher standard of living (wages) in developed countries will be reflected in the higher price of developed country exports relative to those of developing countries. In most cases, exports from the two regions are distinct and so developed country prices are not forced down by the lower cost competition from developing countries. Under these circumstances any productivity gains in developing countries will lower costs of domestic production and then be passed on as lower prices of exports and lower prices for consumers in developed countries (Hunt, 1989).

Unequal Exchange has become a pressing reality for Bangladeshi textile exporters. Although Bangladesh has a small share of global exports it 
has a significant share of global textile exports. The share of South Asia in the global textiles market increased from 7.4 percent in 2000-04 to 11.4 percent in 2010-14 with a full 50 percent of this increase being due to Bangladesh. This share expanded with little change in the composition of exports over 15 years. Approximately 80 percent of Bangladesh's export growth was based on selling more of the same goods to the same destinations, a further 20 percent from selling the same goods to new destinations, while diversification into new products accounted for only 0.07 percent of export growth from Bangladesh (World Bank 2017a, p. 7-8). Productivity growth, implying the ability to produce Bangladesh's existing exports utilizing fewer inputs and so at lower cost may sustain growth for a while longer but Bangladesh is likely to run into market constraints by attempting to export ever more of the same product to the same markets. Gains in productivity in the competitive Walmart textiles market will reduce costs of production and in turn prices. The gains of such a strategy will be more likely to benefit US consumers than Bangladeshi firms and workers.

The missing concept in this discussion of competitiveness and technology is that of structural change. Structural issues are the traditional heart of development policies, whereby the movement of labor from traditional activities in agriculture to the modern sector is key to raising saving, investment, productivity and economic growth. There is a clear stylized fact, that rapidly growing countries are those with large and expanding manufacturing sectors (Rodrik, 2006). Growth accelerations are empirically linked to a rapid increase in the share of manufactured goods in total exports (Johnson et al, 2007) and to increases in the share of manufacturing employment in total employment (Jones \& Olken, 2005). But recent thinking on economic policy has paid much less attention to structural transformation and industrial development.

Bangladesh has proved adept in recent decades at absorbing familiar technology, by using more of the same machines to produce more of the same (textiles output). So in the Bangladeshi case, technology is not irrelevant but technological change must be driven by the need to support structural change, not produce more of the same exports at ever lower cost. This creates a distinct problem for Bangladesh. Unlike investment that expands existing production or replicates well-known technologies, new technologies have an unknown payback period. Technological change tied to structural change will likely require the purchase and financing of new machinery, the training of workers and employees to effectively use new machinery/new processes for new markets/new products and investments in ancillary factors (especially in land) to enable the efficient 
expansion of production. Together this means that structural change utilizing new technologies involve a higher degree of risk and uncertainty (Khan, 2008). In the presence of these learning costs, a latecomer firm (an infant industry) faces a disadvantage relative to established competitors in global markets who have already have undergone the learning process. The unpredictability, lack of information and capital market imperfections endemic to developing countries means that sudden exposure to full import competition can prevent entry into technologically more complex sectors (Khan, 2008). Learning-by-doing may imply a lengthy and unpredictable period of losses as firms learn and adapt technology to make it more appropriate to developing country conditions. Some learning involves serious externalities and coordination problems. In theory, private capital markets could fund firms through the period of learning. In practice, uncertainty, risk and illiquidity mean private capital will be reluctant to do so. In labor-intensive activities such as garment assembly, the wage cost advantage of developing countries may offset the learning costs completely making protection unnecessary. In complex activities with large-scale advanced information and skill needs, wide linkages and organizations, by contrast, the learning process could take decades and might possibly never be undertaken (Lall, 1994). Successful developing countries have frequently created market imperfections to offset these market failures. One such example is that of state provided incentives, known as rents. A rent could be a subsidy that offsets the initial high costs of production, allows a firm to produce, learn how to utilize new technology (engage in a process of learning-by-doing) and eventually become able to compete on world markets. The solution is not to make markets more competitive and perfect (the World Bank strategy) but to intervene and overcome a market failure so to induce structural change.

There are of dangers associated with such rent creation. Firstly, there is a risk of policy failure due to lack of information. The state may not have the information necessary to pick winners. Secondly, rent-seeking theory shows that state-created rents can generate social waste by diverting entrepreneurial energies from productive to unproductive activities like lobbying. Thirdly, state backed rents, once created are difficult to remove and there is plenty of evidence of infant industries that failed to grow up (Chang, 1993). There is evidence that the capacity of the state in Bangladesh has remained stagnant over the past decade and is one not likely to be capable of implementing sophisticated industrial policy reforms. The World Economic Forum (2015) compiled indices, ranging from 1 to 7 (7 being the best) to measure various aspects of governance. Table 1 compares 
World Economic Forum reports from 2006/07 and 2015/163. This reveals no significant change in the low level of state capacity in Bangladesh.

Table 1: Stagnant State Capacity in Bangladesh

\begin{tabular}{|c|c|c|}
\hline Measure of Governance & 2006/07 (rank) & 2015/16 (rank) \\
\hline Quality of Institutions & $2.9\left(121^{\text {st }}\right)$ & $2.9\left(132^{\text {nd }}\right)$ \\
\hline Diversion of Public Funds & $2.4\left(113^{\text {th }}\right)$ & $2.8\left(108^{\text {th }}\right)$ \\
\hline Judicial Independence & $2.5\left(102^{\text {nd }}\right)$ & $2.4\left(130^{\text {th }}\right)$ \\
\hline $\begin{array}{l}\text { Favoritism shown in } \\
\text { decisions of government } \\
\text { officials }\end{array}$ & $2.0\left(119^{\text {th }}\right)$ & $2.2\left(128^{\text {th }}\right)$ \\
\hline $\begin{array}{l}\text { Wastefulness of } \\
\text { Government Spending }\end{array}$ & $2.6\left(99^{\text {th }}\right)$ & $2.6\left(106^{\text {th }}\right)$ \\
\hline Reliability of Police & $2.4\left(119^{\text {th }}\right)$ & $2.6\left(136^{\text {th }}\right)$ \\
\hline $\begin{array}{l}\text { Burden of Government } \\
\text { Compliance }\end{array}$ & $2.4\left(106^{\text {th }}\right)$ & $3.0\left(107^{\text {th }}\right)$ \\
\hline
\end{tabular}

Source: World Economic Forum $(2006,2015)$

A key requirement for a state to implement grand policy and institutional reform is that the bureaucracy be relatively autonomous and so empowered to take a long run growth-promoting view of the economy that is not side-tracked by the populist and short-term demands of politicians. The reality is very different in Bangladesh. Table 1 showed that Bangladesh scores very poorly in terms of the favoritism shown in decisions of government officials. World Bank (2016) notes that policy making in Bangladesh remains "fragmented". There is for example no national trade strategy. The Ministry of Commerce has principal responsibility for domestic and international trade, for trade negotiations, tariffs and non-tariff policy and for ensuring WTO compliance. The Ministry of Commerce lacks the legal knowledge of trade law and lacks the data and analytical resources to keep up with WTO negotiations. The Ministry employed one statistician in 2012 (World Bank, 2016). The Ministry of Industry has responsibility for incentives under the Board of Investment. The Ministry of Finance takes the lead in setting tariffs which are treated as a sub-set of fiscal policy with revenue considerations rather than trade policy being the most important consideration. There is little coherence between import policy (which promotes protection of import substituting, domestic market-oriented and labor intensive industries) and export incentives propagated through the Export Policy and Industrial

\footnotetext{
3 The comparison is marred somewhat by the fact that the 2006/07 report contained only 125 countries and the 2015/16 report 140 countries.
} 
Policy. This has created a highly distortionary incentive environment selected domestic and export sectors are subsidized through high effective rates of protection (World Bank, 2016).

\section{Conclusion}

Much like good governance, "technology" has become a goal that academics' research and policy makers strive for without questioning its ultimate desirability. All technology is good goes this development mantra and policy must focus on issues such as the acquisition, absorption and diffusion of technology by developing countries. This paper and the theory of Unequal Exchange more generally argues that technology cannot be viewed as an unalloyed good. Utilizing new technology in the existing ready-made garment dominated manufacturing economy of Bangladesh will likely lead to few benefits for Bangladeshi firms and workers. The effort of technology adoption will be borne by Bangladeshi firms and workers and the benefits be transferred to US and EU consumers. Technology could be part of a policy solution to help Bangladesh avoid the middle income trap but it must be carefully integrated into a strategy led by the goal of structural change within industry. Technology is ultimately not a neutral scientific process but one in part driven by and in part contributing to the maintenance of a divided global economy. For a dependent developing country technology and technological transfer may perpetuate dependence on foreign imports, royalty and patent payments, and while paying to import new technology developing countries may inadvertently also transfer back to developed countries the benefits of higher productivity and lower costs to those same developed countries. Studies that seek to uncover the influences on and constraints to productivity growth and technological change such as Hussain et al. (2012) and Chaudhry and Faran (2015) need to be supplemented by studies that consider technological transfer in the context of global production, trade and markets. But the true goal for developing countries must remain that of structural change; breaking away from dependence on agriculture and low-tech manufacturing. Technological change can have a valuable role in supporting structural change but should not be valued and pursued for its own sake. 


\section{References}

Asian Development Bank (2016). Bangladesh: Consolidating export-led growth - country diagnostic study, Manila, Philippines.

Cardoso, F. H. (1972). Dependency and development in Latin America. New Left Review, 74, 83-95.

Chang, HJ. (1993). The political economy of industrial policy in Korea. Cambridge Journal of Economics, 17, 131-157.

Chaudhry, T.T. and Faran, M. (2015). Organization, management and wage practices in Pakistan's electrical fan and readymade garment sectors. The Lahore Journal of Economics, 20: SE, 183-204.

Dos Santos, T. (1970). The structure of dependence. The American Economic Review, 60:2, 231-236.

Dreze, J and Sen, A. (2013). An uncertain glory: India and its contradictions. London, Allen Lane.

Emmanuel, A. (1972). Unequal exchange: A study of the imperialism of trade. London, Monthly Review Press.

Felipe, J., Abdon, A. and Kumar, U. (2012). Tracking the Middle Income Trap: What is it, who is in it, and why. Leoy Economics Institute, Working Paper No. 715, New York.

Frank, A.G. (1966). The development of underdevelopment. Monthly Review, $18^{\text {th }}$ September, 4-17.

Hunt, D. (1989). Economic theories of development: An analysis of competing paradigms. London, Harvester Wheatsheaf.

Hussain, S.T., Khan, U., Malik, K.Z. and Faheem, A. (2012). The constraints to industry in Punjab, Pakistan. The Lahore Journal of Economics, 17: SE, 135-189.

Imbs, J. and Wacziarg, R. (2003). Stages of diversification. American Economic Review, 93:1, 63-86.

Jones, B.F. and Olken, B.A. (2008). The anatomy of start-stop growth. The Review of Economics and Statistics, 90:3, 582-587. 
Kabeer, N. and Mahmud, S. (2004). Globalisation, gender and poverty: Bangladesh women workers in export and local markets. Journal of International Development, 16:1, 93-109.

Khan, M.H. (2008). Technological upgrading in Bangladeshi manufacturing: Governance constraints and policy responses in the readymade garments industry. SOAS, London.

Lall, S. (1994). The east Asian miracle: Does the bell toll for industrial strategy. World Development, 22:4, 645-654.

Palma, G. (1978). Dependency: A formal theory of underdevelopment or a methodology for the analysis of concrete situations of underdevelopment. World Development, 6, 881-924.

Psacharopoulos, G. (1994). Returns to investment in education: A global update. World Development. 22:9, 1325-1 343.

Rodrik, D. (2006). Industrial development: Stylized facts and policies. Harvard University, Cambridge.

World Bank (2016). Strengthening competitiveness in Bangladesh - Thematic assessment: A diagnostic trade integration study. Washington, US.

World Bank (2017a). South Asia's turn: Policies to boost competitiveness and create the next export powerhouse. Washington, US.

World Bank (2017b). World development indicators 2017. Accessed 6 $6^{\text {th }}$ March 2017. Data.worldbank.org/data-catalog/world-developmentindicators.

World Economic Forum (2015). The global competitiveness report 2015-2016. Geneva, Switzerland.

Zhang, X., S. Rashid, K.A. and Ahmed, A. (2014). Escalation of real wages in Bangladesh: Is it the beginning of structural transformation. World Development, 64, 273-285. 